\title{
Olfactory Receptor 51E2
}

National Cancer Institute

\section{Source}

National Cancer Institute. Olfactory Receptor 51E2. NCI Thesaurus. Code C132108.

Olfactory receptor 51E2 (320 aa, $\sim 35 \mathrm{kDa}$ ) is encoded by the human OR51E2 gene. This protein may play a role in binding odorant molecules. 